\title{
Successful EMC Project’s Influencing Factors in China
}

\author{
Herui Cui \\ Dept. of Economics and Management, \\ North China Electric Power University, \\ Baoding, China
}

\author{
Yuqi Zhao \\ Economics and Management, \\ North China Electric Power University, \\ Baoding, China
}

\author{
Xu Peng* \\ Dept. of Economics and Management, \\ North China Electric Power University, \\ Baoding, China \\ *Corresponding author
}

\begin{abstract}
Energy Management Contracting is the latest mode in dealing with the energy saving problems in China. It's an effective solution for energy development in the near future. So this paper introduced the factors that influence the success of EMC project. And it explained the success features of EMC project in the macro and micro levels. This paper is a good guideline for establishing an effective EMC project in China, so as to the future development about energy problem happening in China.
\end{abstract} level

Keywords-EMC project; influencing factors; macro \& micro

\section{INTRODUCTION}

In the past 30 years, China's rapid economy growth has led to an average GDP growth of $13 \%$ annually. Even though significantly impacted by natural disasters and the global financial crisis, China in 2008 still achieves an annual GDP growth rate of $9 \%$ [1]. But with the China's rapid economic development, there is a significant increase in energy consumption and the demand for energy is growing, energy supply and reserves far failed to meet the demands. At present, the world's total energy consumption per year is less than 18 billion tons of standard coal [2].

Department of Economics and Dept. of Energy shortages, low energy efficiency,energy waste have become serious bottlenecks restricting China's economic development.

Energy Management Contract (EMC) is an energy-saving service mechanism based on market that refers to energy service companies (ESCO) and energy-consuming enterprises agree upon a certainenergy-saving target on energy efficiency projects in the form of contracts, ESCO provide the necessary services to energy-consuming companies to achieve energy saving goals, energy-consuming companies have to use energy efficiency to pay for the energy services company's investment and reasonable profits [3].

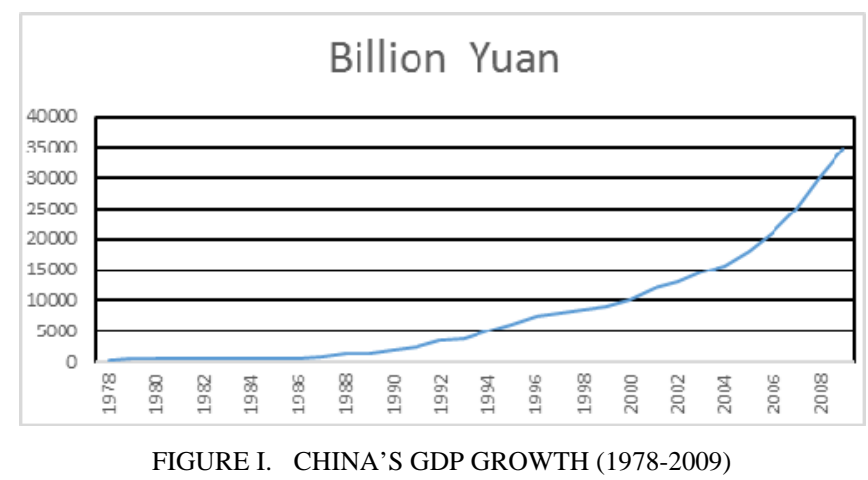

\section{COMPARISON OF EMC MODEL WITH OTHER BUSINESS MODELS}

EMC is a commercial service which as a means to improve energy efficiency, reduce total energy consumption and optimize energy consumption structure and has the purpose of reducing energy consumption.

\section{RESEARCH METHODOLOGY}

A multi-facet qualitative approach is adopted in this paper to identify a list of factors critical for EMC projects in China. The study unfolds in a combination of literature survey, review of case study reports and interviews.

\section{A. Literature survey}

An extensive review of relevant literature was conducted. 
Table.1 Comparison of EMC with other business models

behavior and acceptability should be taken more consideration

\begin{tabular}{|c|c|c|c|c|c|c|}
\hline & Sales & Investment & Loan & $\begin{array}{c}\text { Technical } \\
\text { services and } \\
\text { consult }\end{array}$ & BOT & Finance lease \\
\hline Service content & $\begin{array}{c}\text { Not only } \\
\text { equipment, but } \\
\text { also provide } \\
\text { technical } \\
\text { equipment \& } \\
\text { related services } \\
\text { needed for energy } \\
\text { saving } \\
\end{array}$ & $\begin{array}{l}\text { Investment focuses } \\
\text { on enterprises' } \\
\text { overall profitability } \\
\text { and growth; EMC } \\
\text { focuses on } \\
\text { energy-saving } \\
\text { benefits of the project } \\
\text { itself }\end{array}$ & $\begin{array}{l}\text { Not only provides } \\
\text { project financing, } \\
\text { and provides a } \\
\text { series of technical } \\
\text { services }\end{array}$ & $\begin{array}{l}\text { Providing } \\
\text { multiple } \\
\text { technology } \\
\text { integrated } \\
\text { services }\end{array}$ & $\begin{array}{l}\text { BOT are usually } \\
\text { municipal, } \\
\text { transportation and } \\
\text { other } \\
\text { infrastructure } \\
\text { projects dominated } \\
\text { by the government }\end{array}$ & $\begin{array}{c}\text { Under finance } \\
\text { lease mode, user } \\
\text { can choose } \\
\text { equipment, EMCO } \\
\text { needs to develop } \\
\text { the whole plan for } \\
\text { users }\end{array}$ \\
\hline $\begin{array}{c}\text { Property } \\
\text { ownership }\end{array}$ & $\begin{array}{l}\text { The ownership of } \\
\text { equipment(facilitie } \\
\text { s)belongs to } \\
\text { ESCO during the } \\
\text { contract period }\end{array}$ & $\begin{array}{l}\text { Investment forms } \\
\text { shareholding, } \\
\text { invested enterprises } \\
\text { enjoy legal property } \\
\text { rights }\end{array}$ & $\begin{array}{l}\text { ESCo is necessary } \\
\text { to bear financial } \\
\text { risk and customer } \\
\text { credit risk, but } \\
\text { also fully } \\
\text { responsible for the } \\
\text { technical risks. }\end{array}$ & $\begin{array}{c}\text { Also provides } \\
\text { project } \\
\text { financing }\end{array}$ & $\begin{array}{l}\text { BOT model } \\
\text { generally has the } \\
\text { operation } \\
\text { management by } \\
\text { investors }\end{array}$ & $\begin{array}{l}\text { The ownership of } \\
\text { equipment(facilitie } \\
\text { s)belongs to } \\
\text { ESCO; Under the } \\
\text { finance lease, }\end{array}$ \\
\hline $\begin{array}{c}\text { Service } \\
\text { commitment }\end{array}$ & $\begin{array}{l}\text { Commit to } \\
\text { customers for } \\
\text { energy savings }\end{array}$ & N/A & $\begin{array}{l}\text { Commit to } \\
\text { customers for } \\
\text { energy savings }\end{array}$ & $\begin{array}{l}\text { Commit to } \\
\text { customers for } \\
\text { energy savings }\end{array}$ & $\begin{array}{l}\text { BOT model does } \\
\text { not have to } \\
\text { promise energy } \\
\text { savings to } \\
\text { customers }\end{array}$ & $\begin{array}{l}\text { Commit to } \\
\text { customers for } \\
\text { energy savings }\end{array}$ \\
\hline
\end{tabular}

\section{B. B. Review of case study reports}

Case studies reports of five typical EMC projects that each has different subject.

\section{C. Semi-structured interviews}

The purpose of interviews is to test the literature survey findings and to develop a framework of factors influencing the success of EMC projects in China.

\section{RESULTS}

Through analysis of the collected data in the literature surveys, case study reports review and interviews highlighted a list of 13 factors influencing the success of EMC projects in China. These factors are classified into two levels, i.e. macro level and micro level.

\section{A. Macro level}

1) National policies and regulations: Energy-saving service industry is an emerging industry, companies need government to introduce laws and policies to protect and nurture themselves in the early market.

2) Local government energy policy: China has vast land area and greater economic scale. Due to the different geography environment, industry structure, the level of economic development, the occurring environment of EMC is also different.

3) Incentive mechanism: Gu Xiaodong revealed that the existing laws and policies have no significant penalties for the enterprises whose energy efficiency is low or conduct, accountability mechanism is inadequate.

4) Public awareness and understanding of energy conservation: Public perception, knowledge, attitude, in energy projects [4].

\section{5) Demonstration effect of energy saving}

In order to promote energy conservation and environmental protection, some developed countries take the lead to implement EMC through passing legislations, leading demonstration of government public buildings and other measures, then promote the development of energy service industry.

6) Credit evaluation system: Lack of credibility would jeopardize the viability of the projects[5]. In general, the cycle of energy-saving technological transformation projects which are conducted by EMC model is longer, the interest are returned by phases.

\section{B. Micro level}

1) ESCO's comprehensive ability: Jiang Yue pointed out that EMC projects can be explained that ESCO use new technology to help high energy-consuming enterprises save energy, so whether ESCO have energy-saving technology and whether it has the strength on R\&D of energy-saving technology are fundamental factors in the success of EMC projects.

2) Energy-saving effect detection and identification: Measuring and calculating energy savings or energy-saving rate is the core issues of EMC, because ESCO's income is derived from this.

3) Third party: Energy-saving benefit is a prerequisite and effective guarantee for ESCO and energy-using company to share with the energy savings, but how to determine the energy-saving benefits obtained after the implementation of energy conservation projects is a major problem that hinders the development of EMC. 
4) Project complexity: According to the conclusions of the respondents, the maturity of technology used in projects is likely to affect the smooth development of EMC projects. ESCO are often reluctant to choose those energy-saving projects with high complexity, because the higher the complexity of the project, the higher the technical requirements.

5) Income distribution: Implementation process of energy-saving income distribution integrate in the whole process of implementing EMC projects, the measures of energy-saving effect and the allocation problem of energy saving effect are the issues that energy-using company should make careful consideration to determine whether they can able to choose ESCO to conduct the project.

6) Risk control and management: The most notable feature of the EMC project is that ESCO provide a series of services to the energy-using company. In the implementation process of project, energy-using company has no responsibility and zero risk, but ESCO undertake almost all the risks in project operation [6].

7) Finance factors: Financing is an important part during the implementation of the EMC project. EMC project requires a lot of funds to complete the task of energy saving. According to the operational characteristics of the EMC mechanism, most financing work of EMC project is done by the ESCO [7].

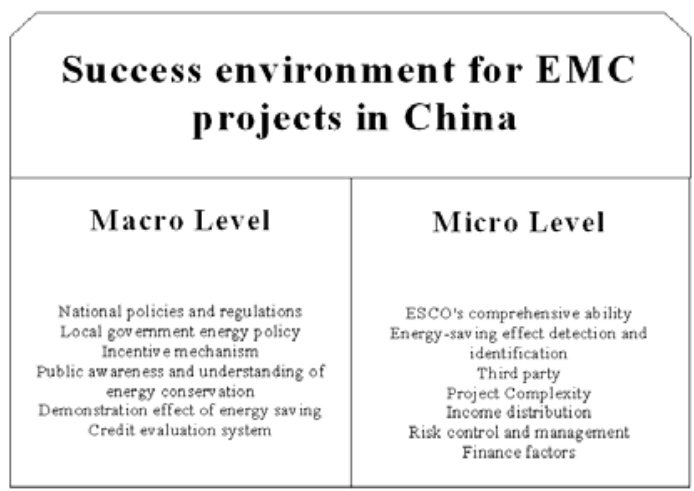

FIGURE II. SUCCESS ENVIRONMENT FOR EMC PROJECT IN CHINA

\section{CONCLUSIONS}

In the past decade, China's economy has achieved rapid development, but at the same time accompanied by rapid growth momentum of a variety of energies. In order to make better energy conservation, promote sustainable development of social and economic, EMC comes into being. China stresses the importance of EMC, and also formulates relevant laws and regulations and establishes reasonable incentive mechanism to promote the development of EMC.

\section{REFERENCES}

[1] Beijing: China Statistics Press; 2010

[2] Li Bao-hua, 2012, Research on the Problem and Countermeasures of the Domestic Energy Management Contracting. Anhui University.
[3] Shen Long-hai. EMC: A New Mechanism of Energy Conversation. China Technology Investment, 2007(7):41-42.

[4] Nikolaos Z, Elli S, Maria P, Georgia N, Vasilios P, Konstantinos PT. Assessment of public acceptance and willingness to pay for renewable energy sources in Crete. Renewable and Sustainable Energy Reviews 2010, 14(3):1088-95.

[5] Xenidis Y, Angelides D. The financial risks in build-operate-transfer projects. Construction Management and Economics 2005;23(4):431-41.

[6] Chen Pan-feng. Analysis of Investment Risk in Energy Management Contracting Project. Journal of Hebei Normal University of Science \&Technology, 2010, 24(1):77-79.

[7] Liang Wei-xian, 2012, Research on the Financing and Risk of Energy Performance Contracting Project. Tsinghua University. 